\title{
No evidence for altered intracellular calcium- handling in airway smooth muscle cells from human subjects with asthma
}

David Sweeney ${ }^{1,2+}$, Fay Hollins ${ }^{1 \dagger}$, Edith Gomez ${ }^{1,2}$, Rajendra Mistry ${ }^{2}$, Ruth Saunders ${ }^{1}$, Robert Alfred John Challiss ${ }^{2^{*}}$ and Christopher Edward Brightling ${ }^{1 *}$

\begin{abstract}
Background: Asthma is characterized by airway hyper-responsiveness and variable airflow obstruction, in part as a consequence of hyper-contractile airway smooth muscle, which persists in primary cell culture. One potential mechanism for this hyper-contractility is abnormal intracellular $\mathrm{Ca}^{2+}$ handling.

Methods: We sought to compare intracellular $\mathrm{Ca}^{2+}$ handling in airway smooth muscle cells from subjects with asthma compared to non-asthmatic controls by measuring: i) bradykinin-stimulated changes in inositol 1,4,5-trisphosphate $\left(\mathrm{IP}_{3}\right)$ accumulation and intracellular $\mathrm{Ca}^{2+}$ concentration, ii) sarco/endoplasmic reticulum $\mathrm{Ca}^{2+}$-ATPase (SERCA) expression, iii) mechanisms of cytoplasmic $\mathrm{Ca}^{2+}$ clearance assessed following instantaneous flash photolytic release of $\mathrm{Ca}^{2+}$ into the cytoplasm.

Results: We found no differences in airway smooth muscle cell basal intracellular $\mathrm{Ca}^{2+}$ concentrations, bradykinin-stimulated $\mathrm{IP}_{3}$ accumulation or intracellular $\mathrm{Ca}^{2+}$ responses. Quantification of SERCA2 mRNA or protein expression levels revealed no differences in ASM cells obtained from subjects with asthma compared to non-asthmatic controls. We did not identify differences in intracellular calcium kinetics assessed by flash photolysis and calcium uncaging independent of agonist-activation with or without SERCA inhibition. However, we did observe some correlations in subjects with asthma between lung function and the different cellular measurements of intracellular $\mathrm{Ca}^{2+}$ handling, with poorer lung function related to increased rate of recovery following flash photolytic elevation of cytoplasmic $\mathrm{Ca}^{2+}$ concentration.

Conclusions: Taken together, the experimental results reported in this study do not demonstrate major fundamental differences in $\mathrm{Ca}^{2+}$ handling between airway smooth muscle cells from non-asthmatic and asthmatic subjects. Therefore, increased contraction of airway smooth muscle cells derived from asthmatic subjects cannot be fully explained by altered $\mathrm{Ca}^{2+}$ homeostasis.
\end{abstract}

Keywords: Asthma, Airway smooth muscle, Calcium, Sarco/endoplasmic reticulum Ca ${ }^{2+}$ ATPase type 2 (SERCA2), Inositol 1,4,5-trisphosphate

\footnotetext{
*Correspondence: jc36@leicester.ac.uk; ceb17@leicester.ac.uk

${ }^{\dagger}$ Equal contributors

${ }^{2}$ Department of Cell Physiology \& Pharmacology, University of Leicester, Henry Wellcome Building, Lancaster Road, Leicester LE1 9HN, UK

'Department of Infection, Immunity \& Inflammation, and Institute for Lung Health, University of Leicester, Glenfield Hospital, Leicester LE3 9QP, UK
} 


\section{Background}

Asthma, a chronic inflammatory disease, remains a major health care burden affecting over 300 million people worldwide. There is a subset of patients that do not respond adequately to traditional treatments, highlighting an urgent need for new therapies [1,2]. Asthma is characterized by variable airflow obstruction and airway hyperresponsiveness as a consequence of increased airway smooth muscle (ASM) contractility [3,4]. An increasing body of evidence supports the view that ASM is fundamentally altered in asthma compared to non-asthmatic controls, suggesting that abnormalities in these structural cells may also play a critical role in the development of the abnormal physiology in asthma and may contribute to the persistent airway inflammation [5-8]. Critically, there is emerging evidence that ASM from asthmatics is hypercontractile, as demonstrated by an increased velocity of contraction in response to electrical field stimulation at the single cell level [9] and in cell populations using gel contraction assays $[5,10]$.

Cytosolic calcium concentration $\left(\left[\mathrm{Ca}^{2+}\right]_{\mathrm{i}}\right)$ plays a cardinal role in ASM contraction. An increase in intracellular ASM $\left[\mathrm{Ca}^{2+}\right]_{i}$ is likely to originate from the sarcoplasmic reticulum of the cell, with evidence of a lesser reliance on $\mathrm{Ca}^{2+}$-influx across the sarcolemma through voltagedependent channels than other muscle types [11-14]. Evidence has accrued to show that ASM calcium homeostasis is abnormal in asthma, suggesting abnormal $\left[\mathrm{Ca}^{2+}\right]_{\mathrm{i}}$ handling, signalling or storage, as possible underlying mechanisms for this hyper-contractility $[11,15,16]$. Resolution of an increase in $\left[\mathrm{Ca}^{2+}\right]_{\mathrm{i}}$ involves the movement of $\mathrm{Ca}^{2+}$ out of the cell through the sarcolemmal $\mathrm{Ca}^{2+}$-ATPase or $\mathrm{Na}^{+} / \mathrm{Ca}^{2+}$-exchangers, or into the sarcoplasmic reticulum through the sarco/endoplasmic reticulum $\mathrm{Ca}^{2+}$-ATPase (SERCA). SERCA2 is the dominant SERCA isoform expressed in ASM, predominantly as the SERCA2B splice variant, and reduced SERCA2 in ASM from subjects with asthma has been reported and proposed to prolong the time for $\left[\mathrm{Ca}^{2+}\right]_{\mathrm{i}}$ to return to baseline following stimulation [11]. To date abnormalities in $\left[\mathrm{Ca}^{2+}\right]_{\mathrm{i}}$ handling in ASM from asthmatics have been explored following agonist-induced activation. Such receptor-dependent changes in $\left[\mathrm{Ca}^{2+}\right]_{\mathrm{i}}$ are often complex, involving complex signal transduction mechanisms that can modulate release and re-uptake of $\left[\mathrm{Ca}^{2+}\right]_{\mathrm{i}}$ at multiple loci. Flash photolysis allows a 'caged' form of calcium to be released in a controlled, time-resolved manner to investigate $\left[\mathrm{Ca}^{2+}\right]_{\mathrm{i}}$ recovery independently of a need for agonist addition [17]. Furthermore by pharmacological inhibition of SERCA activity it is possible to assess the rates of movement of $\mathrm{Ca}^{2+}$ across the sarcoplasmic reticular and/or sarcolemmal membranes to determine if potential asthma-related abnormalities in $\left[\mathrm{Ca}^{2+}\right]_{\mathrm{i}}$ handling are observed independently of the need to perturb $\mathrm{Ca}^{2+}$ homeostasis via receptor-mediated mechanisms.

We hypothesized that $\mathrm{Ca}^{2+}$ handling is abnormal in ASM from subjects with asthma. To test our hypothesis we compared in primary ASM cells from subjects with asthma and non-asthmatic controls: (i) bradykinin-induced changes in intracellular calcium $\left[\mathrm{Ca}^{2+}\right]_{\mathrm{i}}$; (ii) SERCA expression, (iii) agonist-stimulated changes in inositol 1,4,5-trisphosphate $\left(\mathrm{IP}_{3}\right)$ accumulation, and (iv) $\left[\mathrm{Ca}^{2+}\right]_{\mathrm{i}}$ kinetics assessed following release of a $\mathrm{Ca}^{2+}$ load into the cytoplasm by flash photolysis and uncaging.

\section{Methods}

\section{Subjects and cells}

Asthmatic subjects $(\mathrm{n}=20)$ and non-asthmatic controls $(n=18)$ were recruited from Leicester, UK. Asthma severity was defined by Global Initiative for Asthma (GINA) treatment steps (mild-moderate GINA 1-3, severe GINA 4-5) [4]. Primary ASM cells were isolated from bronchial biopsies and used at passages 2-5. The study was approved by the Leicestershire Ethics Committee and patients gave their written informed consent.

\section{Intracellular $\mathrm{Ca}^{2+}$ imaging}

To measure changes in $\left[\mathrm{Ca}^{2+}\right]_{\mathrm{i}}$, ASM cells plated at sub-confluence on coverslips were loaded with $2 \mu \mathrm{M}$ Fura-2 AM (Molecular Probes/Thermo Fisher Scientific) in the presence of $2.5 \mathrm{mM}$ probenecid (Sigma-Aldrich) and $0.04 \% \mathrm{w} / \mathrm{v}$ pluronic F127 (Molecular Probes/Thermo Fisher Scientific), and visualized using an inverted epifluorescence microscope (Nikon Diaphot 200). Changes in Fura-2 fluorescence $(\mathrm{F})$ intensity were measured as a ratio, $\mathrm{R}$, where $\mathrm{R}=\mathrm{F}_{340 \mathrm{~nm}} / \mathrm{F}_{380 \mathrm{~nm}}$, such that $\mathrm{R}$ increases as $\left[\mathrm{Ca}^{2+}\right]_{\mathrm{i}}$ increases [18]. Bradykinin $(1 \mu \mathrm{M})$ was added to ASM cells via perfusion (at $5 \mathrm{~mL} \mathrm{~min}^{-1}$ ) in physiological saline solution (118.4 mM NaCl, $4.7 \mathrm{mM} \mathrm{KCl}, 2.0 \mathrm{mM} \mathrm{CaCl}_{2}$, $1.2 \mathrm{mM} \mathrm{MgCl}$, $11.1 \mathrm{mM}$ glucose, 10 mM HEPES, $\mathrm{pH}$ 7.4) at $37^{\circ} \mathrm{C}$.

\section{Real-time reverse transcription-polymerase chain reaction}

Real-time reverse transcription-polymerase chain reaction was performed (SuperScript Vilo cDNA synthesis kit, Express SYBR-GreenER qPCR Supermix Universal; Invitrogen). Relative quantification was done using the comparative $2^{-\Delta \Delta \mathbf{C t}}$ method [19] and expressed as fold change. The internal normalizer gene was $18 \mathrm{~S}$ rRNA amplified with 18S primer forward (h18SRNA.891 F: GTTGGTTTTCGGAACTGAGG) and 18S reverse primer (h18SRNA.1090R: GCATCGTTTATGGTCGGAAC); amplification of SERCA2A/B/C was with primers forward (serca2abc7608F: CCTGTGCATGACTGATGTTG) and reverse (serca2abc7808R: CAGAGCCTCATTCCTCT TGC). 


\section{$\mathrm{IP}_{3}$ mass assay}

ASM cell monolayers in 24 well plates were stimulated with different concentrations of bradykinin (0.001-10 $\mu \mathrm{M})$. Preliminary experiments demonstrated that $\mathrm{IP}_{3}$ accumulated rapidly after bradykinin addition and was maximal at $10 \mathrm{sec}$. Incubations were terminated by rapid aspiration and addition of trichloroacetic acid $(0.5 \mathrm{M})$. Acid extracts were neutralized and $\mathrm{IP}_{3}$ accumulation measured using a competitive binding assay as described previously [20]. $\mathrm{IP}_{3}$ accumulation is expressed as pmol mg $\mathrm{mg}^{-1}$ of cell protein.

\section{Flash photolysis $/ \mathrm{Ca}^{2+}$ uncaging}

ASM cells plated at sub-confluence on coverslips were co-loaded with $2 \mu \mathrm{M}$ Fluo-4 AM and $2.5 \mu \mathrm{M}$ nitrophenyl-EGTA AM (NP-EGTA AM; Invitrogen [18]) in the presence of $2.5 \mathrm{mM}$ probenecid and $0.04 \% \mathrm{w} / \mathrm{v}$ pluronic F127 in physiological saline solution (see above for composition). $\mathrm{Ca}^{2+}$ transients were monitored using an Olympus confocal laser scanning inverted microscope (FV1000). The single scan head was used to monitor changes in $\left[\mathrm{Ca}^{2+}\right]_{\mathrm{i}}$ by detecting fluo-4 fluorescence with the $488 \mathrm{~nm}$ line of a multi-line argon laser (at 2\% maximum output) using 'round-trip' mode, with emission occurring at $528 \mathrm{~nm}$ and a wide confocal aperture setting of $374 \mu \mathrm{m}$. Near instantaneous switching allows photo-activation/uncaging, with a $405 \mathrm{~nm}$ laser flash without bleaching or response saturation, then switching back to $488 \mathrm{~nm}$ monitoring to capture the subsequent recovery of the cell towards basal $\left[\mathrm{Ca}^{2+}\right]_{\mathrm{i}}[17,21]$. Intensitytime traces, with an image time interval of $32.77 \mathrm{~ms}$, extending over $26 \mathrm{~s}$ were acquired with $\mathrm{a} \times 60 / 1.2 \mathrm{NA}$ oil-immersion objective with $\times 6$ optical zoom. Uncaging pulses of the same intensity were delivered with the $405 \mathrm{~nm}$ laser (100\%) for $300 \mathrm{~ms}$ in 'tornado' mode in a region of interest of diameter 15 pixels, selected in an area of the cytoplasm away from the nucleus. Each cell tested was only flashed once. On the microscope stage, coverslips were placed into a $1 \mathrm{~mL}$ chamber of an open perfusion microincubator (PDMI-2, Harvard Apparatus). Cells were maintained at $37^{\circ} \mathrm{C}$ and perfused at a rate of

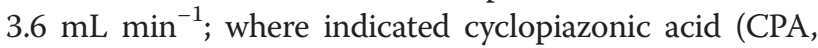
$10 \mu \mathrm{M}$, Sigma-Aldrich) was added to the perfusion solution. Intensity-time curves were analysed by performing a non-linear two phase exponential curve fit with a recovery rate $\mathrm{K}\left(\mathrm{s}^{-1}\right)$ derived for each trace. Mean $\mathrm{K}$ values were calculated for each donor/subject and comparison made between asthma and health/normal. Control experiments were performed using cells loaded with Fluo-4 AM only (no NP-EGTA AM) to confirm that the $405 \mathrm{~nm}$ flash did not perturb $\left[\mathrm{Ca}^{2+}\right]_{\mathrm{i}}$ per se.

\section{Assessment of ASM contraction by collagen gel analysis} Collagen gels $(299 \mu \mathrm{l}$ of collagen (Inamed Biomaterials), $37 \mu \mathrm{l}$ of 10X DMEM (Invitrogen), $20 \mu \mathrm{l}$ of sodium bicarbonate (Invitrogen) were impregnated with $0.25 \times$ $10^{6}$ ASM cells resuspended in $144 \mu \mathrm{l}$ of serum-free medium with stimulus as required. The gels were added to 24-well plates (PBS/0.5\% BSA) and left to polymerize at $37^{\circ} \mathrm{C}$ for $90 \mathrm{~min}$. The gels were then detached and suspended in $500 \mu \mathrm{l}$ of serum-free medium with stimulus as required. Bradykinin (Sigma-Aldrich) was added to appropriate wells to a final concentration of $1 \mathrm{nM}$, with photographs taken at regular intervals up to 1 hour. The surface area of each gel was measured at each time point using ImageJ (http://rsb.info.nih.gov/ij) by a blinded observer.

\section{Statistical analysis}

GraphPad Prism (version 6, GraphPad Software, San Diego) and IBM SPSS version 20 (SPSS, Inc., Chicago) were used to perform statistical analysis. Mean (standard error of the mean [S.E.M.]) was used to present parametric data, while median (interquartile ranges [IQR]) was used for non-parametric data. Comparisons between disease states used unpaired Student's $t$-tests for parametric data, or Mann-Whitney tests for non-parametric data. Correlations were performed using either Pearson or Spearman of parametric and non-parametric data, respectively. A $P$ value less than 0.05 was considered statistically significant.

\section{Results}

The clinical characteristics of the ASM donors are as shown in Table 1. An example trace showing the timecourse of the $\left[\mathrm{Ca}^{2+}\right]_{\mathrm{i}}$ response following bradykinin addition is shown in Figure 1A. The average baseline $\left[\mathrm{Ca}^{2+}\right]_{\mathrm{i}}$ was determined for each donor used (Figure 1B) where a minimum of 5 cells per donor were analysed. No differences in $\mathrm{F}_{340} / \mathrm{F}_{380}$ ratio were found between health and disease $(0.68 \pm 0.02$ and $0.64 \pm 0.02$, respectively; $\mathrm{p}=0.15$; Figure $1 \mathrm{~B}$ ), or indeed between ASM cells obtained from subjects with mild/moderate or severe asthma $(0.65 \pm 0.05$ and $0.64 \pm 0.02$, respectively; $\mathrm{p}=0.83$; Figure $1 \mathrm{~B})$. When baseline $\left[\mathrm{Ca}^{2+}\right]_{\mathrm{i}}$ levels were correlated with $\mathrm{FEV}_{1} \%$ predicted and $\mathrm{FEV}_{1} / \mathrm{FVC} \%$, no correlations were identified $(\mathrm{r}=-0.03, \mathrm{p}=0.92$ and $\mathrm{r}=0.11, \mathrm{p}=0.74$, respectively). Following addition of bradykinin $(1 \mu \mathrm{M})$, the change in $\left[\mathrm{Ca}^{2+}\right]_{\mathrm{i}}(\Delta \mathrm{R})$ was not different between nonasthmatic and asthmatic donors (change in $\mathrm{F}_{340} / \mathrm{F}_{380}$ ratio: $0.17 \pm 0.01$ and $0.16 \pm 0.01$, respectively; $\mathrm{p}=0.61$; Figure $1 \mathrm{C}$ ), or between mild/moderate and severe asthma $(0.16 \pm 0.01$ and $0.16 \pm 0.02$, respectively; $p=0.80$; Figure $1 \mathrm{C}$ ). The results for agonist-stimulated changes in $\left[\mathrm{Ca}^{2+}\right]_{\mathrm{i}}$ did not correlate with $\mathrm{FEV}_{1} \%$ predicted and $\mathrm{FEV}_{1} / \mathrm{FVC} \%(\mathrm{r}=-0.21$, $\mathrm{p}=0.56$ and $\mathrm{r}=-0.19, \mathrm{p}=0.60$, respectively). The area under the curve (AUC) values measured following bradykinin stimulation also did not significantly differ between health and disease (8.24[5.63-13.20] and 6.97[6.05-7.96], 
Table 1 Clinical and functional characteristics of subjects

\begin{tabular}{|c|c|c|c|}
\hline Characteristic & Normal & Mild-moderate asthma GINA 1-3 & Severe asthma GINA 4-5 \\
\hline Number & 18 & 9 & 11 \\
\hline Age & $48(4.2)$ & $43(5.6)$ & $48(3.9)$ \\
\hline Male/Female & $10 / 8$ & $3 / 6$ & $9 / 2$ \\
\hline \multicolumn{4}{|l|}{ Smoking status } \\
\hline Never/Ex/Current & $12 / 2 / 4$ & $7 / 1 / 1$ & $5 / 2 / 4$ \\
\hline Pack years $^{+}$ & $29.0(12.2)$ & $5(0.0)$ & $19.5(8.4)$ \\
\hline $\mathrm{FEV}_{1} \%$ predicted & $97.0(2.9)$ & $89.1(7.5)$ & $95.2(4.3)$ \\
\hline $\mathrm{FEV}_{1} / \mathrm{FVC} \%$ & $79.8(1.7)$ & $71.9(3.3)^{*}$ & $69.6(2.1)^{*}$ \\
\hline \multicolumn{4}{|l|}{ Treatments } \\
\hline LABA (\% of patients) & 0 & 11 & 100 \\
\hline ICS (\% of patients) & 0 & 67 & 100 \\
\hline Dose (bdp) & - & $533.3(84.3)$ & $1636(152.1)$ \\
\hline OCS (\% of patients) & 0 & 0 & 36 \\
\hline Dose (mg/day) & - & - & $8.8(0.7)$ \\
\hline
\end{tabular}

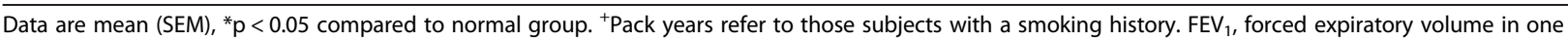
second; FVC, forced vital capacity; LABA, long-acting $\beta_{2}$ adrenoceptor agonist; ICS, inhaled corticosteroid; OCS, oral corticosteroid.

respectively; $\mathrm{p}=0.71$; Figure $1 \mathrm{D})$, or between mild/moderate and severe asthma (6.97[6.27-7.05] and 8.67[6.039.72], respectively; $\mathrm{p}=0.87$; Figure $1 \mathrm{D})$. These data also did not correlate with $\mathrm{FEV}_{1} \%$ predicted and $\mathrm{FEV}_{1} / \mathrm{FVC} \%$ $(\mathrm{r}=-0.06, \mathrm{p}=0.86$ and $\mathrm{r}=-0.06, \mathrm{p}=0.86$, respectively). Finally, the rate of recovery following administration of bradykinin did not differ between ASM cells from nonasthma and asthma subjects (0.02[0.02-0.02] and 0.02 [0.02-0.03], respectively; $\mathrm{p}>0.99$; Figure $1 \mathrm{E})$, or between mild/moderate and severe asthma (0.02[0.02-0.04] and $0.03[0.02-0.03]$, respectively; $\mathrm{p}=0.17$; Figure $1 \mathrm{E})$.

The relative expression of SERCA2A/B/C mRNA was assessed in 10 non-asthmatic control subjects and 13 patients with asthma (Figure 2A). Expression was not found to alter between health and disease (1.09[0.90-1.16] and $0.97[0.85-1.26]$, respectively; $\mathrm{p}=0.60$; Figure $2 \mathrm{~A}$ ), or between mild/moderate and severe asthma (0.97[0.77-1.10] and 1.06[0.86-1.37], respectively; $\mathrm{p}=0.62$; Figure 2A). There was no correlation either with $\mathrm{FEV}_{1} \%$ predicted and $\mathrm{FEV}_{1} / \mathrm{FVC} \%(\mathrm{r}=0.37, \mathrm{p}=0.22$ and $\mathrm{r}=-0.29, \mathrm{p}=0.32$, respectively). Example western blots showing total SERCA2 protein and $\beta$-actin in ASM cells derived from four asthma patients and three non-asthmatic donors are shown in Figure 2B. Densitometry of total SERCA2 immunoreactivity from western blots showed that there was no significant difference in SERCA2 protein expression in normal $(n=10)$ compared to asthma $(n=10)$ ASM cell donors (106 \pm 7 and $107 \pm 5$, respectively; $p=0.90$; Figure 2C). Differences in protein expression were not found between asthma GINA 1-3 and GINA 4-5 (107 \pm 7 and $109 \pm 10$, respectively; $\mathrm{p}=0.84$; Figure $2 \mathrm{C}$ ). In addition, these data do not correlate with $\mathrm{FEV}_{1} \%$ predicted and
$\mathrm{FEV}_{1} / \mathrm{FVC} \%(\mathrm{r}=-0.07, \mathrm{p}=0.85$ and $\mathrm{r}=-0.01, \mathrm{p}=0.99$, respectively).

Concentration-dependent $\mathrm{IP}_{3}$ accumulation responses to bradykinin were assessed in ASM cells derived from 8 non-asthmatic and 11 asthmatic patients. Typical concentration-response curves are shown for ASM cells obtained from a non-asthmatic or an asthmatic patient (Figure 3A). The bradykinin concentrations causing a half-maximal increase in $\mathrm{IP}_{3}$ accumulation $\left(\mathrm{EC}_{50}\right)$ were not significantly different between non-asthmatic and asthmatic smooth muscle donors $\left(-\log \mathrm{EC}_{50}(\mathrm{M}): 7.17 \pm\right.$ 0.11 and 7.22 \pm 0.10 , respectively; $\mathrm{p}=0.74$; Figure $3 \mathrm{~B})$, nor between mild/moderate and severe asthma (7.40 \pm 0.09 and $7.06 \pm 0.14$, respectively; $p=0.08)$. No correlation was found with $\mathrm{FEV}_{1} \%$ predicted and $\mathrm{FEV}_{1} / \mathrm{FVC} \%(\mathrm{r}=-0.38$, $\mathrm{p}=0.15$ and $\mathrm{r}=-0.48, \mathrm{p}=0.14$, respectively). The increase in $\mathrm{IP}_{3}$ accumulation (basal-to-peak; $\Delta \mathrm{IP}_{3}$ ) following stimulation was not significantly different between health and disease $\left(\Delta \mathrm{IP}_{3}\right.$ (pmol mg $\mathrm{pm}^{-1}$ protein): $631 \pm 68$ and $647 \pm 54$, respectively; $\mathrm{p}=0.86$; Figure $3 \mathrm{C}$ ). Accumulation was not found to differ either between asthma GINA 1-3 and GINA 4-5 (576 \pm 68 and $707 \pm 77$, respectively; $\mathrm{p}=0.25)$. Maximal changes in $\mathrm{IP}_{3}$ accumulation stimulated by bradykinin did not correlate with $\mathrm{FEV}_{1} \%$ predicted and $\mathrm{FEV}_{1} / \mathrm{FVC} \%(\mathrm{r}=0.01, \mathrm{p}=0.98$ and $\mathrm{r}=-0.02, \mathrm{p}=0.96$, respectively).

Comparisons of $\left[\mathrm{Ca}^{2+}\right]_{\mathrm{i}}$ recovery rates following $\mathrm{Ca}^{2+}$ uncaging in the absence or presence of SERCA inhibition were made in ASM cells from patients with asthma or non-asthmatic controls (example traces shown in Figure 4A). There was no significant difference in the mean $\mathrm{Ca}^{2+}$ uncaging recovery rate between health and disease 

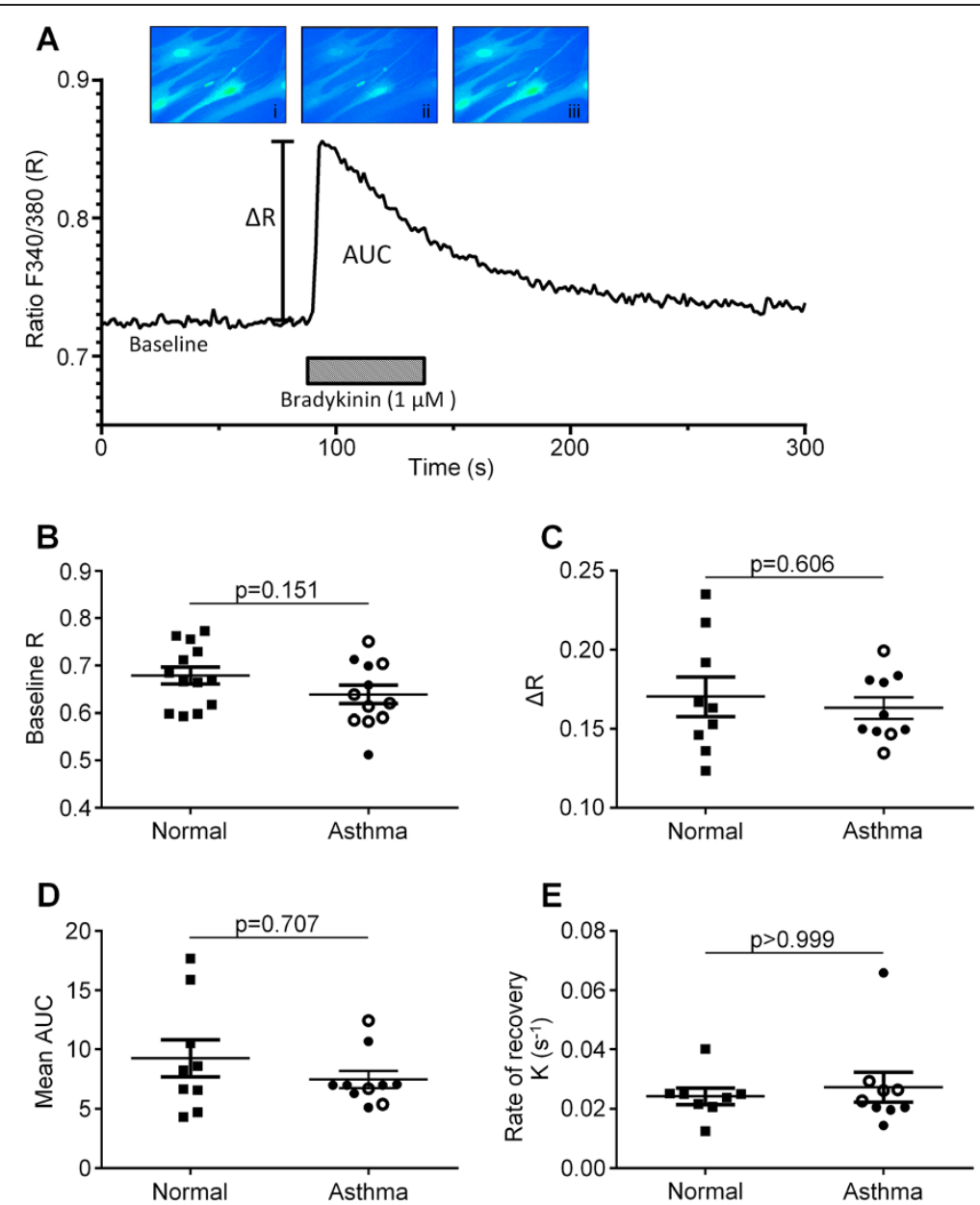

Figure 1 Responses of ASM cells isolated from asthmatic and non-asthmatic subjects to bradykinin addition. (A) Representative graph showing a $\left[\mathrm{Ca}^{2+}\right]_{i}$ response to bradykinin $(1 \mu \mathrm{M})$. Measurements taken from these $\mathrm{Ca}^{2+}$ responses were mean change in $\mathrm{F}_{340 \mathrm{~nm}} / \mathrm{F}_{380 \mathrm{~nm}}$ ratio $(\Delta \mathrm{R})$, baseline $\mathrm{Ca}^{2+}$ concentration (expressed as $F_{340 \mathrm{~nm}} / F_{380} \mathrm{~nm}$ ratio), area under the curve (AUC), and the rate of decline from the peak $\mathrm{Ca}{ }^{2+}$ response. The baseline $\left[\mathrm{Ca}^{2+}\right]_{\mathrm{i}}(\mathbf{B})$, peak increase in $\left[\mathrm{Ca}^{2+}\right]_{\mathrm{i}}$ following bradykinin stimulation (C), AUC during the agonist addition (D), and rate of decline in $\left[\mathrm{Ca}^{2+}\right]_{i}$ from the peak bradykinin-stimulated response (E) were measured for each ASM cell donor across a range of cells (6-40 cells per donor) and the average value for each variable plotted for non-asthmatic and asthmatic donors. Symbol key: filled circles: GINA 1-3; open circles: GINA 4-5; filled squares: non-asthmatic donors. Parametric data (B, C) displayed as mean (SEM) and analysed by Student's t-test. Non-parametric data (D, E) displayed as median (IQR) and analyzed using Mann-Whitney.

either in the absence of CPA $\left(\mathrm{K}_{-\mathrm{CPA}}\left(\mathrm{s}^{-1}\right): 3.31 \pm 0.46\right.$ and $3.89 \pm 0.58$, respectively; $\mathrm{p}=0.45$; Figure $4 \mathrm{~B})$, or when SERCA was inhibited, $\left(\mathrm{K}_{+\mathrm{CPA}}\left(\mathrm{s}^{-1}\right): 1.43 \pm 0.23\right.$ and $1.29 \pm 0.15$, respectively; $p=0.60$; Figure 4 C). Similarly, no differences were seen in recovery rates between mild/moderate and severe asthma in the absence $\left(\mathrm{K}_{\mathrm{CPA}}\right.$ : $3.80 \pm 0.88$ and $3.99 \pm 0.83$, respectively; $\mathrm{p}=0.88)$ or presence $\left(\mathrm{K}_{+\mathrm{CPA}}: 1.24 \pm 0.25\right.$ and $1.34 \pm 0.19$, respectively; $\mathrm{p}=$ 0.77; Figure 4C) of SERCA inhibition. The difference between $\mathrm{K}_{-\mathrm{CPA}}$ and $\mathrm{K}_{+\mathrm{CPA}}(\Delta \mathrm{K})$ values in ASM cells from non-asthmatic and asthmatic patients did not reveal any differences $(\Delta \mathrm{K}: 1.88 \pm 0.51$ and $2.61 \pm 0.49$, respectively; $\mathrm{p}=0.32$ ), nor was there a difference between asthma GINA classification $1-3$ and $4-5(\Delta \mathrm{K}: 2.56 \pm 0.76$ and $2.65 \pm 0.69$, respectively; $\mathrm{p}=0.93$ ).
Correlations were observed in the subjects with asthma between lung function and $\mathrm{Ca}^{2+}$ uncaging recovery rates with and without SERCA inhibition by CPA (Figure 5). There was a trend correlating the mean $\mathrm{Ca}^{2+}$ uncaging recovery rate with $\mathrm{FEV}_{1} \%$ predicted $\left(\mathrm{r}_{\mathrm{s}}=-0.565, \mathrm{p}=0.053\right.$; Figure $5 \mathrm{~A}$ ), which was no longer observed when SERCA activity was inhibited $\left(r_{s}=-0.244, p=0.423\right.$; Figure $\left.5 C\right)$. A trend was also observed between the $\mathrm{FEV}_{1} / \mathrm{FVC} \%$ and $\mathrm{Ca}^{2+}$ uncaging recovery rates $\left(r_{s}=-0.518, p=0.085\right.$; Figure $\left.5 B\right)$, which was statistically significantly correlated when SERCA activity was inhibited $\left(\mathrm{r}_{\mathrm{s}}=-0.652, \mathrm{p}=0.024\right.$; Figure $5 \mathrm{D}$ ). When the difference between the mean $\mathrm{Ca}^{2+}$ uncaging recovery rates with and without CPA $(\triangle \mathrm{K})$ was compared with $\mathrm{FEV}_{1} \%$ predicted, there was again a significant negative correlation $\left(r_{s}=-0.647, p=0.023\right.$; 


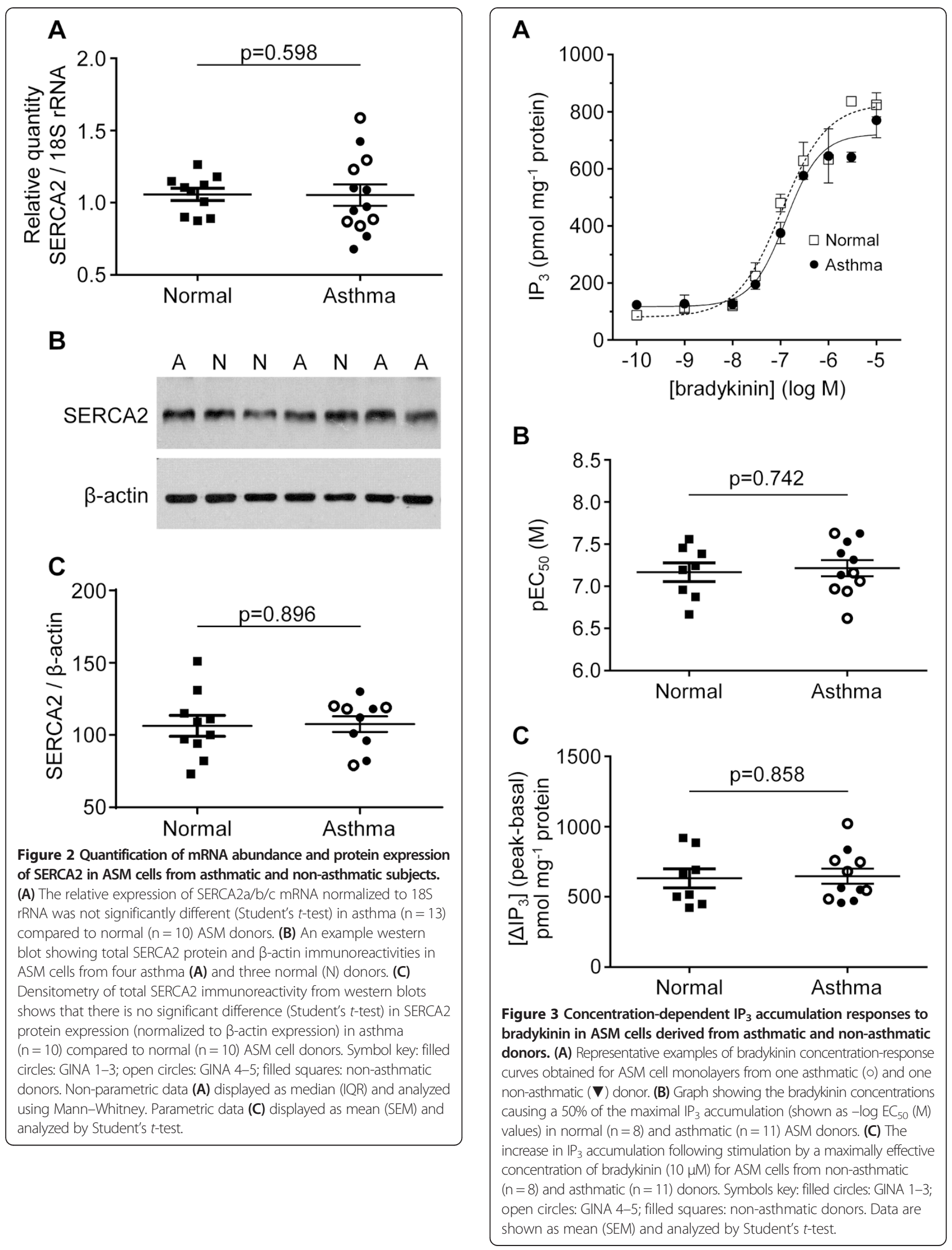



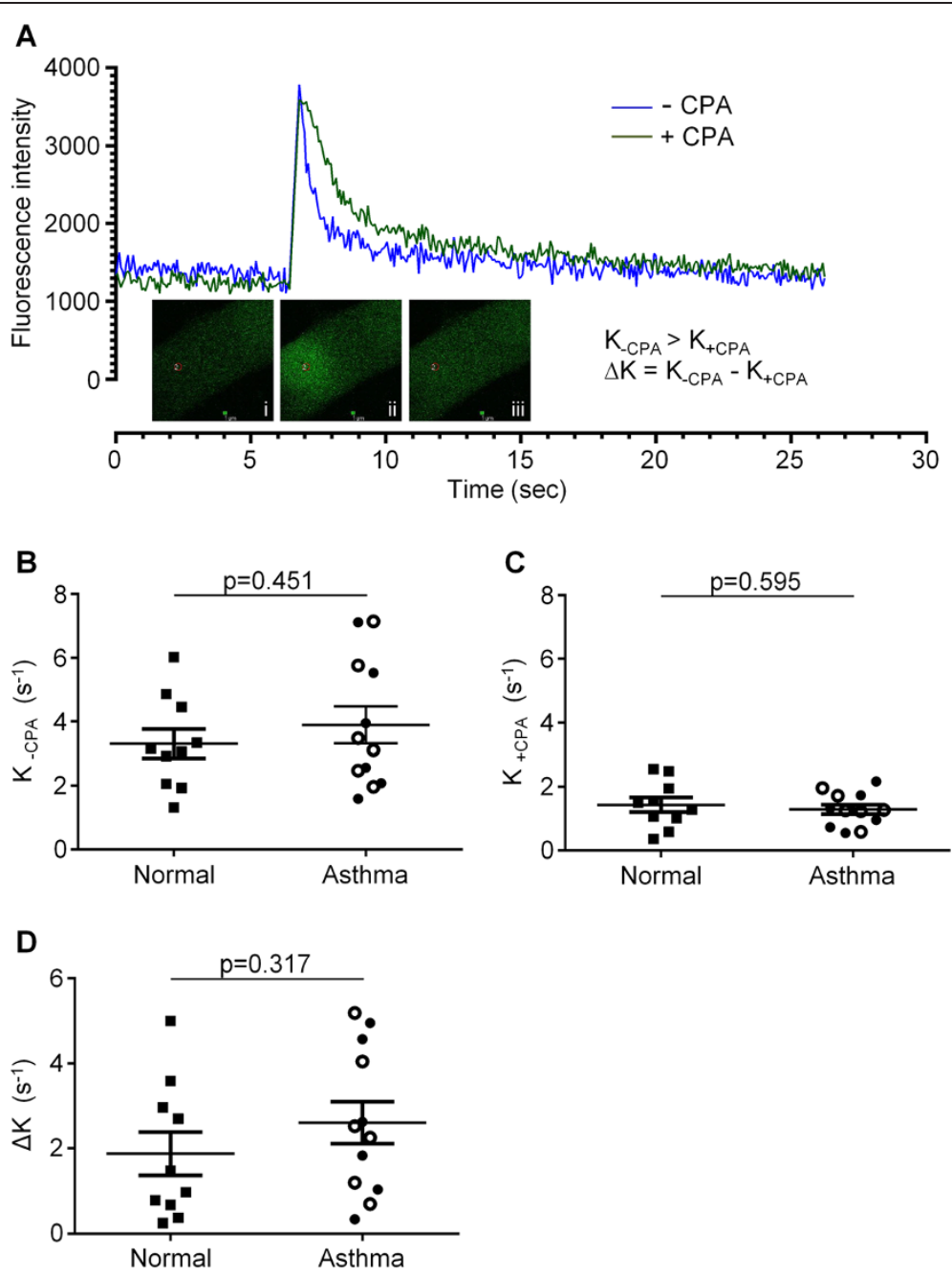

Figure 4 Assessing the recovery of $\left[\mathrm{Ca}^{2+}\right]_{\mathrm{i}}$ following $\mathrm{Ca}^{2+}$-uncaging in ASM cells derived from asthmatic and non-asthmatic donors. (A) Representative examples of changes in $\left[\mathrm{Ca}^{2+}\right]_{i}$ on photolysis of the NP-EGTA Ca ${ }^{2+}$ cage and the subsequent rate of recovery to pre-uncaging levels of $\left[\mathrm{Ca}^{2+}\right]_{i}$. Changes in $\left[\mathrm{Ca}^{2+}\right]_{i}$ are shown for ASM cells in the absence (blue line) or presence (green line) of the SERCA inhibitor, CPA $(10 \mu \mathrm{M})$. Inset example photographs of $\mathrm{Ca}^{2+}$ uncaging using a confocal microscope before (i), during (ii) and after (iii) the $405 \mathrm{~nm}$ laser flash. (B) Mean $\mathrm{Ca}^{2+}$ uncaging recovery rates (K-CPA) without SERCA inhibition in ASM cells from normal $(n=10)$ and asthma $(n=10)$ donors. (C) Mean $\mathrm{Ca}^{2+}$ uncaging recovery rates when SERCA is inhibited $\left(K_{+}\right.$CPA $)$in ASM cells from normal $(n=10)$ and asthma $(n=12)$ donors. (D) The difference between $K_{C P A}$ and $K_{+C P A}(\triangle K)$, which represents primarily trans-plasmalemmal efflux of $\mathrm{Ca}^{2+}$ in ASM cells, is also plotted for each normal $(n=10)$ and asthmatic $(n=12)$ donor. Symbol key: filled circles: GINA 1-3; open circles: GINA 4-5 filled squares: non-asthmatic donors. Data are shown as mean (SEM) and analyzed by Student's t-test.

Figure 5E), but not with $\mathrm{FEV}_{1} / \mathrm{FVC} \%\left(\mathrm{r}_{\mathrm{s}}=-0.354\right.$, $\mathrm{p}=0.252$; Figure 5F).

In 17/38 ASM donors, agonist-induced contraction was assessed. The ASM from asthmatic was hypercontractile (mean difference in area under the curve contraction \pm SEM; $5127 \pm 140 ; 4274 \pm 207 ; \mathrm{p}=0.023 ;$ non-asthmatic compared to asthmatic respectively; Figure $6 \mathrm{~A}$ and $\mathrm{B}$ ). Area under the curve contraction was not related to $\Delta \mathrm{R}$, but was related to $\mathrm{K}$ and $\Delta \mathrm{K}(\mathrm{r}=0.04 ; \mathrm{p}=0.93$; $\mathrm{r}_{\mathrm{s}}=-0.691 ; \mathrm{p}=0.023 ; \mathrm{r}_{\mathrm{s}}=-0.618 ; \mathrm{p}=0.048$ respectively; data not shown).

\section{Discussion}

Here we have studied $\left[\mathrm{Ca}^{2+}\right]_{\mathrm{i}}$ handling by low passage primary ASM cells from subjects with asthma compared to non-asthmatic controls. Our findings demonstrate no differences in basal $\left[\mathrm{Ca}^{2+}\right]_{\mathrm{i}}$, agonist-induced peak $\left[\mathrm{Ca}^{2+}\right]_{\mathrm{i}}$ responses or recovery following agonist activation. Concentration-dependent accumulations of the second messenger $\mathrm{IP}_{3}$ in response to bradykinin addition were not different in ASM cells from subjects with asthma versus non-asthmatic controls, although there was a small, significant increase in maximal bradykinin-stimulated $\mathrm{IP}_{3}$ 

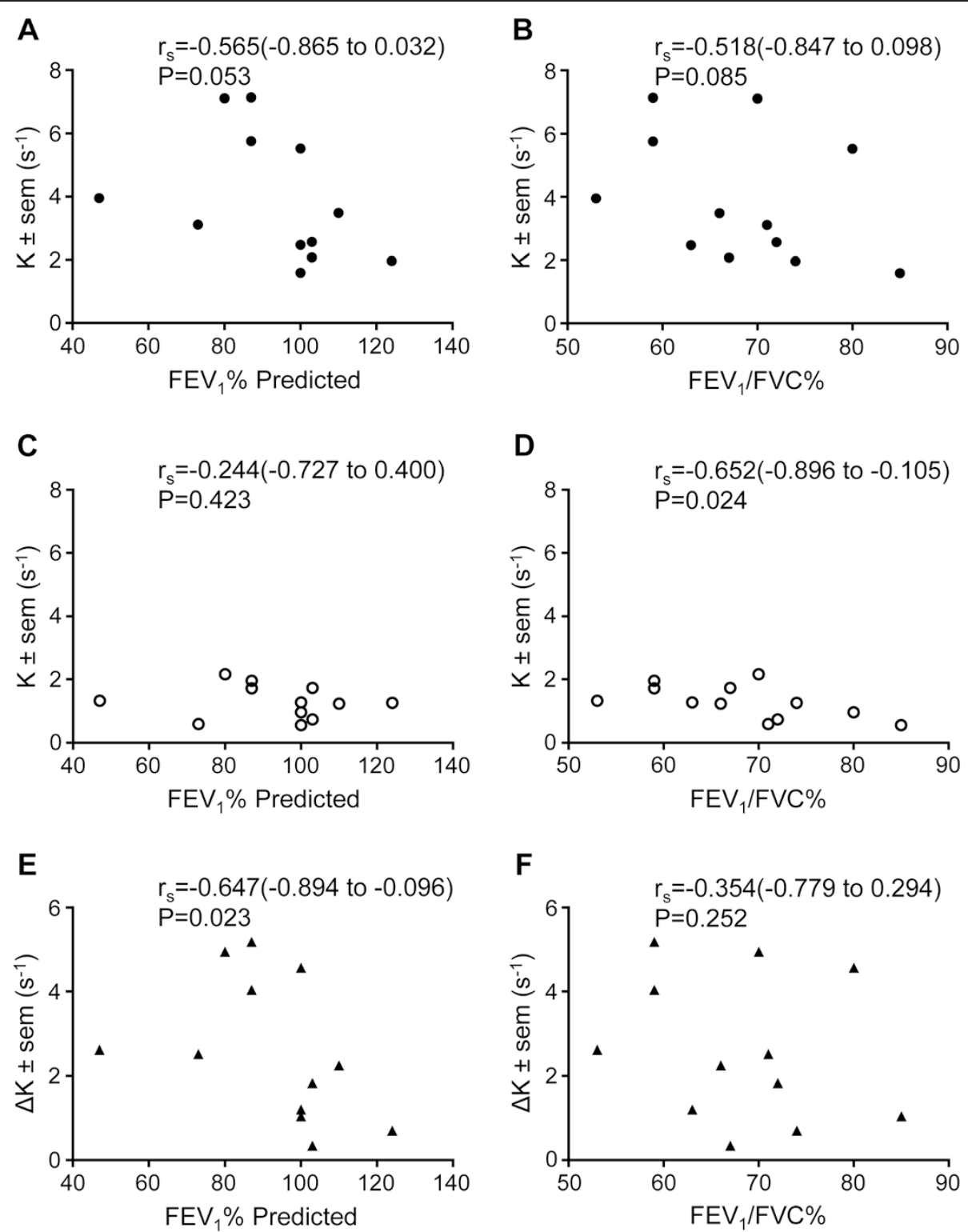

- $\mathrm{K}-\mathrm{CPA} O \mathrm{~K}+\mathrm{CPA} \Delta \triangle \mathrm{K}$

Figure 5 Correlations of rates of recovery following $\mathrm{Ca}^{2+}$ uncaging in ASM cells with clinical lung function parameters in respective patient donors. Recovery rates compared to the $\mathrm{FEV}_{1} \%$ predicted $(\mathbf{A}, \mathbf{C}, \mathbf{E})$ and $F E V_{1} / F V C \%(\mathbf{B}, \mathbf{D}, \mathbf{F})$ are shown in the absence of inhibitor $(-C P A, \bullet, A, B)$, in the presence of CPA $(+C P A, \circ, C, D)$, or for the difference between $-C P A$ and $+C P A$ recovery rates $(\triangle K, \mathbf{\Lambda}, \mathbf{E}, \mathbf{F})$. Data were analyzed by Spearman correlation ( $95 \%$ confidence interval).

responses when severe (GINA 4-5) and mild-moderate (GINA 1-3) asthma patients were compared. We did not identify any differences in SERCA2 mRNA or protein expression. $\left[\mathrm{Ca}^{2+}\right]_{\mathrm{i}}$ kinetics assessed by flash photolysis and calcium uncaging independent of agonist-activation again did not demonstrate differences in rates of recovery of $\left[\mathrm{Ca}^{2+}\right]_{\mathrm{i}}$ either with or without SERCA inhibition. However, we did observe correlations in the subjects with asthma between lung function and $\left[\mathrm{Ca}^{2+}\right]_{i}$ rate of recovery following flash photolysis with poorer lung function relating to an increased rate of recovery. Taken together this study does not support a fundamental difference in $\left[\mathrm{Ca}^{2+}\right]_{\mathrm{i}}$ handling in ASM from subjects with asthma compared to non-asthmatic controls per se, but does not exclude a possible contribution in specific phenotypes, such as those with impaired lung function, as suggested here by subtle differences in $\left[\mathrm{Ca}^{2+}\right]_{\mathrm{i}}$ recovery rates.

Our findings of no disease-related differences in agonistinduced evoked changes in $\left[\mathrm{Ca}^{2+}\right]_{\mathrm{i}}$ conflicts with work published previously $[11,15,16]$. Mahn and colleagues reported 

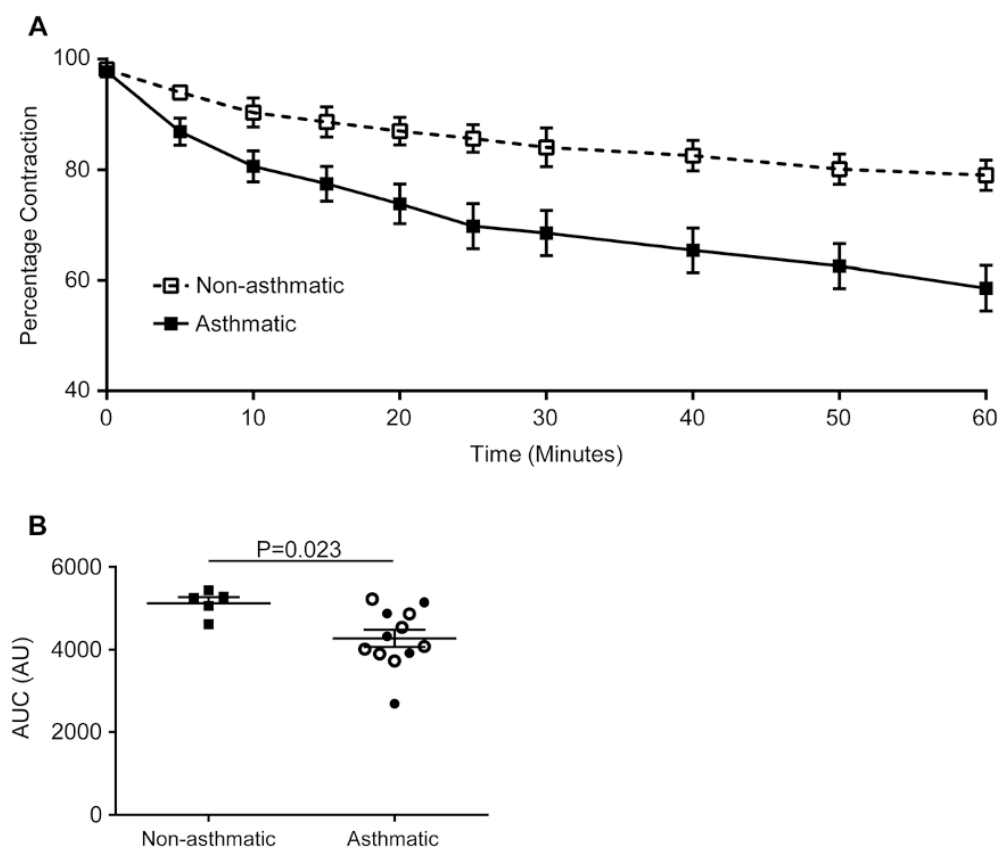

Figure 6 Collagen gel contraction assay of human airway smooth muscle cells. (A) Percentage contraction of collagen gels impregnated with airway smooth muscle from donors who are not asthmatic $(n=5)$ and donors with asthma $(n=12)$ over 1 hour following stimulation with 1 nM bradykinin. (B) Area under the curve gel contraction. Symbol key: filled circles: GINA 1-3; open circles: GINA 4-5; filled squares: non-asthmatic donors.

Data are shown as mean \pm SEM and analysed by Student's t-test.

a reduced peak $\left[\mathrm{Ca}^{2+}\right]_{\mathrm{i}}$ response to the same concentration of bradykinin [11], a reduced response to ryanodine $(1 \mu \mathrm{M})$ and thapsigargin $(0.1 \mu \mathrm{M})$ in ASM cells from asthmatic versus non-asthmatic donors. Similarly, Trian et al. reported a reduced $\left[\mathrm{Ca}^{2+}\right]_{\mathrm{i}}$ response to acetylcholine $(10 \mu \mathrm{M})$ or histamine $(10 \mu \mathrm{M})$ in ASM cells from asthmatic subjects [16]. Interestingly, in contrast to our report, the healthy control and asthma subjects were not age matched and whether calcium handling is altered by age of the donor is unknown. We have been unable to confirm these earlier findings and did not observe associations between agonist-induced $\left[\mathrm{Ca}^{2+}\right]_{\mathrm{i}}$ peak or rate of recovery with severity of disease defined by GINA treatment steps, nor with lung function. Our study had $80 \%$ power to observe a 0.05 difference between health and disease in $\left[\mathrm{Ca}^{2+}\right]_{\mathrm{i}}(\Delta \mathrm{R})$ following bradykinin activation. Mahn et al. reported $\left[\mathrm{Ca}^{2+}\right]_{\mathrm{i}}(\Delta \mathrm{R})$ of 0.07 and 0.12 between ASM from non-asthmaticsubjects versus those with either mild or moderate asthma, respectively [11]. Therefore, our study had sufficient power to observe the differences reported previously. Thus, it would seem likely that the differences found here compared to earlier reports reflect the heterogeneity of the disease and indicate that changes in $\left[\mathrm{Ca}^{2+}\right]_{\mathrm{i}}$ in response to agonist might be altered in some asthmatics. Therefore, whether altered $\left[\mathrm{Ca}^{2+}\right]_{\mathrm{i}}$ handling is typically altered in asthma requires further study in a larger population.

In addition to our inability to replicate earlier reports of differences in agonist-evoked changes in $\left[\mathrm{Ca}^{2+}\right]_{i}$ we were also unable to demonstrate differences in SERCA2 expression, either at the mRNA or protein levels. Mahn et al. found reduced expression of both mRNA and protein in primary ASM cells and reduced expression in ASM in vivo in tissue sections of endobronchial biopsies, in both moderate and severe asthmatics compared to non-asthmatic controls [11]. We did not investigate SERCA2 expression in tissue and therefore cannot exclude the possibility of differential expression in vivo, but our findings do not support a fundamental change in SERCA expression in disease, nor a relationship with disease severity determined by either treatment requirement or lung function. Again our study was sufficiently powered to observe the differences described by Mahn et al. and therefore, the most plausible explanation is that decreased SERCA expression is not a consistent feature of ASM from subjects with asthma.

We report for the first time a comparison of the concentration dependency and magnitude of changes in the $\mathrm{Ca}^{2+}$-mobilizing second messenger $\mathrm{IP}_{3}$ in response to bradykinin in ASM cells from subjects with asthma compared to health. We did not find any differences between health and disease, or disease severity. Here we also extended the exploration of intracellular $\left[\mathrm{Ca}^{2+}\right]_{\mathrm{i}}$ handling to investigate the differences in ASM cells from subjects with asthma and non-asthmatic controls independent of agonist. $\left[\mathrm{Ca}^{2+}\right]_{\mathrm{i}}$ kinetics assessed by flash photolysis and calcium uncaging independent of agonist- 
activation again did not demonstrate differences in rates of recovery of $\left[\mathrm{Ca}^{2+}\right]_{i}$ either with or without SERCA inhibition. Interestingly, we did observe correlations in the subjects with asthma between lung function and rates of recovery of $\left[\mathrm{Ca}^{2+}\right]_{i}$ following flash photolysis. Those asthmatics with poorer lung function had greater rates of $\left[\mathrm{Ca}^{2+}\right]_{\mathrm{i}}$ recovery. This again conflicts with the report from Mahn et al., which suggests that rates of recovery are reduced in asthma [11,15]. Similar correlations between spontaneous calcium oscillation frequency and lung function were observed previously [22]. Whether there is a common mechanism between spontaneous oscillations and rate of recovery in $\left[\mathrm{Ca}^{2+}\right]_{\mathrm{i}}$ following flash photolysis requires further investigation. However, although the correlations reported here are intriguing, they are only observed in those ASM cells from subjects with asthma and there were no differences in uncaging $\left[\mathrm{Ca}^{2+}\right]_{\mathrm{i}}$ rate of recovery between asthma and health, questioning whether these relationships are important.

In contrast to the inconsistency of the observations relating to $\left[\mathrm{Ca}^{2+}\right]_{\mathrm{i}}$ handling in ASM cells from subjects with asthma, we and others have consistently found that primary ASM cells from asthmatics are hyper-contractile $[5,9-11]$. Contraction in ASM is driven by $\left[\mathrm{Ca}^{2+}\right]_{\mathrm{i}}$ originating from the sarcoplasmic reticulum stores, therefore, the hyper-contractility seen in asthma is likely to be due to abnormalities in $\left[\mathrm{Ca}^{2+}\right]_{\mathrm{i}}$ handling, $\mathrm{Ca}^{2+}$ sensitivity or changes to the contractile machinery. Since we have not shown here any intrinsic abnormality in $\left[\mathrm{Ca}^{2+}\right]_{\mathrm{i}}$ or SERCA2 in ASM cells derived from asthmatic patients when compared with non-asthmatic subjects, we must consider alternative mechanisms. Myosin light-chain kinase (MLCK) is a major player in this $\mathrm{Ca}^{2+} /$ contraction pathway and indeed others have found expression of MLCK to be increased [11,23]. Up-regulation of the $\mathrm{Ca}^{2+}$-independent rhoA/rho kinase signalling pathway leads to inhibition of myosin light-chain phosphatase resulting in increased levels of phosphorylated myosin light-chains and increased ASM contraction force at a given increase in $\left[\mathrm{Ca}^{2+}\right]_{\mathrm{i}}[24]$. Abnormalities within this pathway have been reported in animal models $[25,26]$. Beyond the $\mathrm{Ca}^{2+} /$ contraction pathway, increased production of reactive oxygen species (ROS) can damage tissue; indeed, the oxidative burden is increased in asthma. Nicotinamide adenine dinucleotide phosphate oxidase 4 (NOX4), an important source of ROS, is increased in asthmatics and hyper-contractility of ASM from asthmatic patients, seen in gel-contraction assays, could be abolished following the addition of NOX4 inhibitors or transfection with small interfering RNAs targeting NOX4 [5]. Pathways, such as cAMP signalling that mediate bronchorelaxation, for example cAMP dependent PKA inhibits MLCK by reducing its affinity for $\mathrm{Ca}^{2+}$ / CaM (reviewed in [27]), may also be differentially regulated in ASM from subjects with asthma versus health. Furthermore, phosphodiesterase (PDE) 4 and prostaglandin $(\mathrm{PG}) \mathrm{E}_{2}$ are differentially expressed in ASM from asthmatic and healthy donors, and might contribute to increased contration in asthma $[28,29]$. These and other mechanisms need to be explored further in future studies.

Our study has a number of potential limitations. We have used primary ASM cells and therefore whether important mechanisms present in vivo persist in culture is uncertain. However, our ability to observe hypercontractility in primary ASM from asthmatics does suggest the mechanism driving this abnormality persists in vitro and therefore our inability to demonstrate altered $\left[\mathrm{Ca}^{2+}\right]_{\mathrm{i}}$ handling remains important. Perhaps more critical is the heterogeneity of asthma and even though our study has sufficient power to observe large differences in $\left[\mathrm{Ca}^{2+}\right]_{\mathrm{i}}$ handling we might have failed to observe small, albeit important, differences in specific phenotypes of asthma. For example, our intriguing observations of correlations between lung function and $\left[\mathrm{Ca}^{2+}\right]_{\mathrm{i}}$ rates of recovery following NP-EGTA $\mathrm{Ca}^{2+}$ uncaging might reflect important associations in a sub-group of asthmatics.

\section{Conclusions}

In summary, we have not shown major fundamental differences in $\mathrm{Ca}^{2+}$ handling between ASM from subjects with and without asthma, in contrast to previous reports $[11,16]$, we conclude that differences in contraction between asthmatic and non-asthmatic subject-derived primary ASM cells cannot be fully explained by altered $\left[\mathrm{Ca}^{2+}\right]_{\mathrm{i}}$ homeostasis in asthma.

\section{Abbreviations}

$\left[\mathrm{Ca}^{2+}\right]_{i}$ : Cytosolic calcium concentration; ASM: Airway smooth muscle; AUC: Area under the curve; CAMP: Cyclic adenosine monophosphate; CPA: Cyclopiazonic acid; F: Fluorescence; FEV 1 : Forced expiratory volume in one second; FVC: Forced expiratory vital capacity; GINA: Global Initiative for

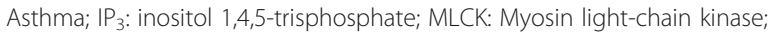
NOX4: Nicotinamide adenine dinucleotide phosphate oxidase 4; PKA: Protein kinase A; R: Ratio; ROS: Reactive oxygen species; SERCA: sarco/endoplasmic reticulum $\mathrm{Ca}^{2+}$-ATPase.

\section{Competing interests}

CE Brightling serves on advisory boards for GlaxoSmithKline, AstraZeneca, Medlmmune, Roche, and Aerovance; receives honoraria from Novartis; and receives research support from GlaxoSmithKline, AstraZeneca, and Medlmmune. The rest of the authors have declared that they have no competing interests.

\section{Authors' contributions}

DS carried out the intracellular calcium measurement and calcium uncaging assays, participated in the experimental design, data analysis and drafted the manuscript. FH carried out the intracellular calcium measurement and collagen gel assays, participated in the experimental design, data analysis and drafted the manuscript. EG carried out the SERCA2 measurement and data analysis. RM carried out the $\mathrm{IP}_{3}$ accumulation assays and data analysis. RS participated in data analysis. RAJC conceived the study, participated in the design and data analysis, and drafted the manuscript. CEB conceived the study, participated in the design and data analysis, and drafted the manuscript. All authors read and approved the final manuscript. 


\section{Acknowledgements}

We acknowledge the expert help provided by Dr Kees Straatman (Advanced Imaging Facility, Core Biotechnology Services, University of Leicester) with the flash photolysis experiments.

Received: 17 September 2014 Accepted: 3 February 2015 Published online: 13 February 2015

\section{References}

1. Chung KF, Wenzel SE, Brozek JL, Bush A, Castro M, Sterk PJ, et al. International ERS/ATS guidelines on definition, evaluation and treatment of severe asthma. Eur Respir J. 2014;43:343-73.

2. Brightling CE, Gupta S, Gonem S, Siddiqui S. Lung damage and airway remodelling in severe asthma. Clin Exp Allergy. 2012;42:638-49.

3. Bousquet J, Mantzouranis E, Cruz AA, Aït-Khaled N, Baena-Cagnani CE, Bleecker ER, et al. Uniform definition of asthma severity, control, and exacerbations: document presented for the World Health Organization Consultation on Severe Asthma. J Allergy Clin Immunol. 2010;126:926-38.

4. Global Strategy for Asthma Management and Prevention. Global Initiative for Asthma (GINA) 2014. http://www.ginasthma.org. Updated May 2014. Accessed 8th September 2014.

5. Sutcliffe A, Hollins F, Gomez E, Saunders R, Doe C, Cooke M, et al. Increased nicotinamide adenine dinucleotide phosphate oxidase 4 expression mediates intrinsic airway smooth muscle hypercontractility in asthma. Am J Respir Crit Care Med. 2012;185:267-74.

6. Brightling CE, Ammit AJ, Kaur D, Black JL, Wardlaw AJ, Hughes JM, et al. The CXCL10/CXCR3 axis mediates human lung mast cell migration to asthmatic airway smooth muscle. Am J Respir Crit Care Med. 2005;171:1103-8.

7. Johnson PR, Roth M, Tamm M, Hughes M, Ge Q, King G, et al. Airway smooth muscle cell proliferation is increased in asthma. Am J Respi Crit Care Med. 2001;164:474-7.

8. An SS, Bai TR, Bates JH, Black JL, Brown RH, Brusasco V, et al. Airway smooth muscle dynamics: a common pathway of airway obstruction in asthma. Eur Respir J. 2007;29:834-60.

9. Ma X, Cheng Z, Kong H, Wang Y, Unruh H, Stephens NL, et al. Changes in biophysical and biochemical properties of single bronchial smooth muscle cells from asthmatic subjects. Am J Physiol Lung Cell Mol Physiol. 2002;283:L1181-899.

10. Matsumoto H, Moir LM, Oliver BG, Burgess JK, Roth M, Black JL, et al. Comparison of gel contraction mediated by airway smooth muscle cells from patients with and without asthma. Thorax. 2007;62:848-54.

11. Mahn K, Hirst SJ, Ying S, Holt MR, Lavender P, Ojo OO, et al. Diminished sarco/endoplasmic reticulum $\mathrm{Ca}^{2+}$ ATPase (SERCA) expression contributes to airway remodelling in bronchial asthma. Proc Natl Acad Sci U S A. 2009;106:10775-80.

12. Hirota $S$, Helli $P$, Janssen $\sqcup$. lonic mechanisms and $\mathrm{Ca}^{2+}$ handling in airway smooth muscle. Eur Respir J. 2007;30:114-33.

13. Black JL, Panettieri Jr RA, Banerjee A, Berger P. Airway smooth muscle in asthma: just a target for bronchodilation? Clin Chest Med. 2012;33:543-58.

14. Perez-Zoghbi JF, Karner C, Ito S, Shepherd M, Alrashdan Y, Sanderson MJ. Ion channel regulation of intracellular calcium and airway smooth muscle function. Pulm Pharmacol Ther. 2009;22:388-97.

15. Mahn K, Ojo OO, Chadwick G, Aaronson PI, Ward JP, Lee TH. $\mathrm{Ca}^{2+}$ homeostasis and structural and functional remodelling of airway smooth muscle in asthma. Thorax. 2010;65:547-52.

16. Trian $T$, Benard G, Begueret $H$, Rossignol R, Girodet PO, Ghosh D, et al. Bronchial smooth muscle remodeling involves calcium-dependent enhanced mitochondrial biogenesis in asthma. J Exp Med. 2007;204:3173-81.

17. Ellis-Davies GCR, Kaplan JH. Nitrophenyl-EGTA, a photolabile chelator that selectively binds $\mathrm{Ca}^{2+}$ with high affinity and releases it rapidly upon photolysis. Proc Natl Acad Sci U S A. 1994;91:187-91.

18. Grynkiewicz G, Poenie M, Tsien RY. A new generation of $\mathrm{Ca}^{2+}$ indicators with greatly improved fluorescence properties. J Biol Chem. 1985;260:3440-50

19. Mori R, Wang Q, Danenberg KD, Pinski JK, Danenberg PV. Both $\beta$-actin and GAPDH are useful reference genes for normalization of quantitative RT-PCR in human FFPE tissue samples of prostate cancer. Prostate. 2008;68:1555-60.

20. Challiss RAJ, Batty IH, Nahorski SR. Mass measurements of inositol 1,4,5 trisphosphate in rat cerebral cortex slices using a radioreceptor assay: effects of neurotransmitters and depolarization. Biochem Biophys Res Commun. 1988:157:684-91.
21. Ji G, Feldman M, Doran R, Zipfel W, Kotlikoff Ml. $\mathrm{Ca}^{2+}$-induced $\mathrm{Ca}^{2+}$ release through localized $\mathrm{Ca}^{2+}$ uncaging in smooth muscle. J Gen Physiol. 2006;127:225-35

22. Sweeney D, Hollins F, Gomez E, Saunders R, Challiss RAJ, Brightling CE. $\left[\mathrm{Ca}^{2+}\right]_{i}$ oscillations in ASM - relationship with persistent airflow obstruction in asthma. Respirology. 2014;19:763-6.

23. Benayoun L, Druilhe A, Dombret MC, Aubier M, Pretolani M. Airway structural alterations selectively associated with severe asthma. Am J Respir Crit Care Med. 2003;167:1360-8.

24. Schaafsma D, Gosens R, Zaagsma J, Halayko AJ, Meurs H. Rho kinase inhibitors: a novel therapeutical intervention in asthma? Eur J Pharmacol. 2008;585:398-406.

25. Chiba Y, Matsusue K, Misawa M. RhoA, a possible target for treatment of airway hyperresponsiveness in bronchial asthma. J Pharmacol Sci. 2010;114:239-47

26. Chiba Y, Takada Y, Miyamoto S, Mitsui-Saito M, Karaki H, Misawa M. Augmented acetylcholine-induced, Rho-mediated $\mathrm{Ca}^{2+}$ sensitization of bronchial smooth muscle contraction in antigen-induced airway hyperresponsive rats. Br J Pharmacol. 1999;127:597-600.

27. Billington CK, Hall IP. Novel CAMP signalling paradigms: therapeutic implications for airway disease. Br J Pharmacol. 2011;166:401-10.

28. Patel BS, Prabhala P, Oliver BG, Ammit AJ. Inhibitors of PDE4, but Not PDE3, Increase $\beta 2$-agonist-induced Expression of Anti-inflammatory MKP-1 in Airway Smooth Muscle Cells. Am J Respir Cell Mol Biol 2014 [Epub ahead of print]

29. Van Ly D, Faiz A, Jenkins C, Crossett B, Black JL, McParland B, et al. Characterising the mechanism of airway smooth muscle $\beta 2$ adrenoceptor desensitization by rhinovirus infected bronchial epithelial cells. PLoS One. 2013;8(2):e56058

\section{Submit your next manuscript to BioMed Central and take full advantage of:}

- Convenient online submission

- Thorough peer review

- No space constraints or color figure charges

- Immediate publication on acceptance

- Inclusion in PubMed, CAS, Scopus and Google Scholar

- Research which is freely available for redistribution

Submit your manuscript at www.biomedcentral.com/submit
C) BioMed Central 